\title{
Educational Institutions and Information Asymmetry Observation in UAE
}

\section{Amjad Khan Suri ${ }^{1 *}$ and Adnan $\mathbf{J}^{2}$}

${ }^{1}$ Department of Business administration, Banasthali Vidyapit, India

${ }^{2}$ Department of Business administration, Khawarizmi international college, UAE

\begin{abstract}
Nobel Prize winner Akerlof proposed lemon theory and showed how information asymmetry in the market creates an unbalanced information where poor quality offerings (lemons) wipe out good quality offerings in the market. Akerlof's model was originally developed in the context of used cars in the market where lemon problem was frequently observed. However, the theoretical problem lemon is not limited to the car market but also valid in other markets with the same situations. The present study focuses on information asymmetry observed in the education system in UAE because of an "information gap" due to the asymmetric information.
\end{abstract}

Keywords: Adverse selection; Moral hazard; Agency; Information asymmetry; Lemon; Universities; Colleges

\section{Introduction}

Adverse selection was first pioneered by George Akerlof in his article "The Market for Lemons: Quality Uncertainty and the Market Mechanism", which examined the markets for insurance, used motor vehicles, employment and credit [1]. Akerlof explores adverse selection by the use of asymmetric quality information about the purchase of used motor vehicles to show market failure and observed price differentials between new and used cars and explored why they occur. When selling the car, the owner knows whether the sold car is a good car or a "lemon". A prospective buyer has limited information that some cars are good and some are lemons that result in information asymmetry between the car's seller and prospective buyer. Finally, the seller has more information that distorts the negotiating process and creates failure in the market efficiency as "bad cars drive out the good because they sell at the same price as good cars". Akerlof's model premise could be tested in other similar market situations where asymmetric information exists between buyers and sellers. Nearly, 70 universities and colleges in UAE offering the whole gamut of educational courses which are each vying for a larger share of the diminishing student [2]. Universities' and colleges' in the UAE attract students with information about their academic programs in terms of job placements and the real practical market learning's.

Huge amount of money is pumped into educational institutes on advertisements and promotions. Publicity by word of mouth from previous students, friends and work mates could be an influencing factor in decision making. With the multitude of available options in education, applicants have very limited time to explore the real learning's and comparing the program of study with other universities or colleges. In reality, most student select low university for studies and the emanating competition reinforce "lemon" theory that low quality universities wipe out good quality universities. Instead, students join university program with superficial appeal or to institutions with established reputations but poor learning's. University worthiness is assessed on the basis of the changes in the available information with all the stakeholders. An analysis is done to check the relation on whether education and information are enough to empower decision makers to make "good" decisions.

Successful economic growth of the country depends upon the proficiency of the educated population. Hence, every government sets up the minimum standard for attaining the basic academic proficiency for every student in the country. However, many students failed to meet the basic educational proficiency required in the job market. From the plethora of university information available is quiet perplexing to students in university selection and mostly settle in low quality universities with the available information. Students finally spend more money and resources by selecting the low quality relevant academic program due to the lack of proper knowledge and judgment. Thus, information asymmetry in educational market leads to poor selection of the program. Stiglitz discovered that obtaining information is costly, and information asymmetries sometimes exist and affect agents' behavior that has a profound effect on understanding otherwise puzzling phenomena [3].

Jackson and McConnell, defines "Economics is concerned with the efficient use of limited productive resources for the purpose of attaining the maximum satisfaction of our material wants", and economic agents undertake those transactions that satisfy their wants [4]. Economic agents are not aware of the market situations in respect of each educational program available in the market. Examples of this include that the students do not know the price of a particular course at each university offers with universities also facing the similar dilemmas over the selection of the students. Universities now face an uphill struggle on student's selection whose skills are not commensurate with the requirement of the university program. Most of the quality universities apply stringent selection criterion to select students on the basis of the GPA secured in the previous graduating exam. The problem will be exacerbated further if student secure high GPA but having less analytical mental state. It seems probable therefore, that obtaining information in individual markets being too costly, or impossible to obtain in the distribution of asymmetric information. The lack of information in a market transaction may be only one sided, or be evident to both parties $[5,6]$.

*Corresponding author: Amjad KS, Department of Business administration Khawarizmi international college, UAE, Tel: +971 22015 000; E-mail: amjadkhansuri@gmail.com

Received July 12, 2016; Accepted September 05, 2016; Published September 09, 2016

Citation: Suri AK, Adnan J (2016) Educational Institutions and Information Asymmetry Observation in UAE. J Glob Econ 4: 213. doi: 10.4172/23754389.1000213

Copyright: ( 2016 Suri AK, et al. This is an open-access article distributed under the terms of the Creative Commons Attribution License, which permits unrestricted use, distribution, and reproduction in any medium, provided the original author and source are credited. 


\section{Asymmetric Information}

Asymmetric information rises when one party is in advantageous position to another party and widens the differential information to economic agents so that the university has more or less detailed information about the quality of the student, or employee will know more about the ability about their employer. An asymmetricinformation problem that occurs when the behaviour of one party is unobservable by the other party after a contract is agreed. These two forms of asymmetric information, Moral Hazard and adverse selection- is frequently cited in Insurance to explain inefficiencies/ failures in the distribution of information. Economists always consider asymmetric information in the analysis of markets, as it tends to create a situation where low quality products drive out good quality products. It's difficult to establish the complexity of the items being traded with the availability of asymmetric information in the particular product market. Therefore, it is not just the uncertainty economic agent's face, but the distribution of the asymmetry of information shared between agents that can influence their actions in the market. Information asymmetry is observed rampantly in:

- Reputation - High Quality University is differentiated from low quality university by its reputation.

- Standardization-The purpose is to standardize education reputation. Harvard University in America is an outstanding example.

\section{Moral Hazard}

Varian defines moral hazard as situations where one side of the market cannot observe the actions of the other economic agent and referred it as hidden action problem. A common moral hazard phenomena observed on driving insured motor vehicle recklessly than driving uninsured vehicle. Gibson found moral hazard problem impedes market to reach equilibrium and causes failure in reaching efficiency in the insurance market, because individual's incentives are altered by not having to worry about their post contractual actions in regards to the insured event [7]. Moral hazard happens when effort is not observable and would inhibit the free information sharing (Table 1).

\section{Adverse Selection}

Also known as hidden information problem in a market, where sellers may know more about a product than a customer Estrin and Laidler and incorporate the information asymmetry, where one party in a transaction does not know the characteristics about the other party but knows something about its own characteristics [8]. Universities in UAE could be tested with the Akerlof's model on the premise that there are two types of universities available, high quality or low quality. With the university knowing the quality of the program offered that cannot be judged by the qualifying student. A simplified numerical example explains the results of quality differences: Universities in UAE offers courses from graduate level to doctorate level in UAE with the list of the programs available on the university portal [9]. Varian tests the car model based on costs of low quality and high quality motor vehicles proves mathematically how low quality car wipes out high quality cars [6]. The price they are willing to pay, also affects the sale of all good quality motor vehicles. The graduate program offered in all the major universities ranging from life science to business studies. To understand the flow of information asymmetry following examples with hypothetical cost is made to test the asymmetry. The low graded universities in UAE offers bachelor degree with business major on an average AED 30000 for full time two year program and high graded university offers the same duration program for AED 800000 for full program, and students will be willing to pay $\$ 45000$ for a low quality university and AED100000 for a high quality university graduate program. Buyers will have to estimate how much a graduation degree is worth, and assume that the probability of obtaining a high or low quality education is equal. If a student will pay the expected value of a graduation degree, then they would be willing to pay $0.5^{\star} 45000+0.5^{\star} 100000=$ AED 72500 .

The only seller willing to sell would be that of the low graded program $(\$ 30000<\$ 72500<\$ 80000)$. Therefore, low graded program would offer for sale. Students would expect to get a low graded university program and not a high graded university program. Market failure will occur because selling a mediocre quality university program affects the buyers perceptions of the quality of all university graduate programs, the price they are willing to pay, and affects the sale of all good quality university program.

\section{Review of Literature}

Analysis of existing literature in higher education suggests that the efficiency of future academic markets depends on the nature of information disseminated on academic quality. Role played by existing quality information among buyers and consumers of higher education is analyzed. The last decade has produced a mammoth shift in governmental thinking about education from the perspective of regulator on reducing the gaps between the good quality and poor quality educational programs. Jongbloed et al. argue that many states are working to improve the proficiency of higher education systems with performance-based funding and other contractual relations [10]. Le Grand and Bartlett found that contractual relations represent a form of quasi-market in which the state purchase services from independent providers, who compete with each other in an internal market and reduce funding in the higher education [11]. Student expresses their choice of educational programs without going for purchases in quasimarket. Universities not only pursue multiple goals, competing objectives, and contentious trade-offs, but the primary goal of higher education is to develop a variety of proxy measures for academic quality have been adopted globally. Cave et al. [12]; Jongbloed et al. [10] pointed out some frequently used performance indicators of academic quality include graduate employment, cost per student, time to degree completion and student non-completion rates. Other performance

\begin{tabular}{|c|c|c|}
\hline Participants & Levels & Information asymmetry \\
\hline Students & $\begin{array}{c}\text { Diabolical assumption about future with present level of education and ready to } \\
\text { spent money and time in gaining another qualification }\end{array}$ & $\begin{array}{c}\text { Students lacks desired information and uninformed real market skills } \\
\text { required in the job market }\end{array}$ \\
\hline Parents & A secured job and a better life after the university degree & $\begin{array}{c}\text { Pay little attention on the practical skills and focus more on the } \\
\text { results secured for their children }\end{array}$ \\
\hline Universities & $\begin{array}{c}\text { Mostly working like a business institution where degrees are products. Pay little } \\
\text { attention on maintain quality and sound academic performance }\end{array}$ & $\begin{array}{c}\text { University have little autonomy to teach practical skills and often } \\
\text { succumb to student ratings, output and working loads }\end{array}$ \\
\hline $\begin{array}{c}\text { Accrediting } \\
\text { agencies }\end{array}$ & $\begin{array}{c}\text { Focus more on international standards like AACSB and Equis with little attention } \\
\text { on checking practical learnings }\end{array}$ & $\begin{array}{c}\text { Using single quality measurement to accredit all the program with } \\
\text { little focus paid on understanding and analytical approach }\end{array}$ \\
\hline
\end{tabular}

Table 1: Information asymmetry observed with key players in education. 
indicators like subjects mix and student's previous qualifications also influence inter-university variation in students' non-completion rate [13]. Holtta et al. discovered different geographical areas face different prices in finland [14]. Johnes explained different disciplinary mixes between universities contribute over two-thirds of the variation of university unit costs in the UK [15]. Ramsden found quality of teaching is highly influenced Student satisfaction indicator [16]. The main challenge of performance indicators is to develop and measure the contribution that universities make for students' personal development with a strong focus on enhancing intellectual abilities.

\section{Case Analysis}

The present day educational scenario is full of fallacies with no focus on developing and enhancing critical thinking in the students. Available ready-made solutions and parroting the education as observed in most of the universities to fetch high grades will not nurture a logical generation with scientific understanding. Self-proclaimed education experts and academically inexperienced run educational affairs and least bother on the providing the real essence of education. Using different hackneyed expressions in teaching methodology, like 20th or 21st century education skills widens information asymmetry. Most of the universities focus on developing several unwarranted skills with no impetus given to students in decision making that are in sync the with industry requirements. Scientific subjects are more analytical and conditions oriented. The present 21 st century skills focus more on preparing our generation for new challenges and pressures. With the global economic turmoil and southward drift on economic indexes could be analyzed to prepare our new generation to focus on questioning rather than believing. Potential students and their parents should have sufficient information about which university to select for the education. Most of the state based funded institutions follows orthodox style of pedagogy and rarely focus on improving the state of the art architecture. This affect will support the "lemon" theory where low graded education university wipes out high graded university in students selection. However, students should be given authority to ask question as a measure to improve and impart quality education and reduce information imperfections in the market of higher education. University programs handbook and prospectus, university visits, meeting with the student advisor, university staff also play an important role in deciding the feasibility of the university program.

\section{Conclusion}

The literature suggested that university education exist within a purview of myriad social actors. Difficulty in assessing the quality of education asymmetry in information dissemination focus on short term benefits over long term benefits in the education market. UAE being the cosmopolitan country with people working from more than 150 countries require higher education to develop skills to face the challenges of the $21^{\text {st }}$ century. In a complex society requiring increasing levels of higher education, citizens have little time for detailed analysis of the inner workings of higher education finance. Yet, they are increasingly affected by the outcomes. From the analysis of asymmetric information it is obvious that students, universities, and the local economy focus on attaining short term economic goals. Universities importance in using innovative way to pass the information about the feasibility and intellectual worthiness of the program is not used by the universities. The umbilical connection without the proper information to various stakeholders in the society makes education difficult to understand with flawed system. Various stakeholders in the society focus on short term goals and cosmetic measures to attain the desired objectives that are not fruitful in the long term. The MOHE (Ministry of higher education) in UAE play an important role in reducing the asymmetry between education and the other stake holders. It is unlikely, though, that MOHE in UAE plays an important role in reducing the gap among various stakeholders in the short term systematically (and the goals are in line with academic freedom as a whole). The renewed impetus for reform in multi-disciplinary factors impact each and every stakeholders will bring a dynamic change in the education system and a better understanding of these factors could provide solutions to forestalling short term goals to override long term goals in education in society at large. Of course, the considerations of cost and benefits in the education are all surmise, but something like considering other stakeholders in decision making must be going on.

\section{References}

1. Akerlof GA (1970) The Market for "Lemons": Quality Uncertainty and the Market Mechanism. Q J Econ 84: 488-500.

2. http://www.mohesr.gov.ae/En/ServicesIndex/Documents/UAE-factbook24Feben-CDversion.pdf

3. Stiglitz JE (2000) The Contribution of the Economics of Information to Twentieth Century Economics. Q J Econ 115: 1441-1478.

4. Jackson J, McConnell CR (1985) Economics. McGraw-Hill, Australia.

5. Stiglitz JE (1993) Economics. WW Norton \& Company, USA.

6. Varian HR (1990) Intermediate Microeconomics: A Modern Approach. WW Norton and Company, USA

7. Gibson HR (1987) Asymmetric Information in Insurance Markets: A Situation of Moral-Hazard.

8. Estrin S, Laidler D (1995) Introduction to Microeconomics. Prentice Hall/ Harvester Wheatsheaf, UK.

9. https://www.caa.ae/caa/DesktopModules/InstInfo.aspx?emirate=Any\&major=A ny\&level=Any;\%20accessed

10. Jongbloed B, Vossensteyn H (2001) Keeping Up Performances: An International Survey of Performance-based Funding in Higher Education. Journal of Higher Education Policy and Management 23: 127-145.

11. Le Grand J, Bartlett W (1993) Quasi-Markets and Social Policy. Macmillan Press, London.

12. Cave M, Hanney S, Henkel M, Kogan M (1997) The Use of Performance Indicators in Higher Education: The Challenge of the Quality Movement Jessica Kingsley Publishing, London.

13. Johnes J, Taylor J (1989) Undergraduate Non-Completion Rates: Difference between UK Universities. Higher Education 18: 209-225.

14. Holtta S, Rekila E (2003) Ministerial Steering and Institutional Responses: Recent Developments of the Finnish Higher Education System. Higher Education Management and Policy 15: 57-70.

15. Johnes J (1990) Unit Costs: Some Explanations of the Difference between UK Universities. Applied Economics 22: 853-862.

16. Ramsden P (1991) A Performance Indicator of Teaching Quality in Higher Education: the Course Experience Questionnaire. Studies in Higher Education 16: $129-150$ 